Article

\title{
Effects of Carrier Materials and Storage Temperatures on the Viability and Stability of Three Biofertilizer Inoculants Obtained from Potato (Solanum tuberosum L.) Rhizosphere
}

\author{
Becky Nancy Aloo ${ }^{1, *}$, Ernest Rashid Mbega ${ }^{2}$, Billy Amendi Makumba ${ }^{3}$ and John Baptist Tumuhairwe 4 \\ 1 Department of Biological Sciences, University of Eldoret, Eldoret P.O. Box 1125-30100, Kenya \\ 2 Department of Sustainable Agriculture and Biodiversity Conservation, Nelson Mandela African Institution of \\ Science and Technology, Arusha P.O. Box 447, Tanzania; ernest.mbega@nm-aist.ac.tz \\ 3 Department of Biological Sciences, Moi University, Eldoret P.O. Box 3900-30100, Kenya; \\ billymakumba@gmail.com \\ 4 Department of Agricultural Production, College of Agricultural and Environmental Sciences, \\ Makerere University, Kampala P.O. Box 7062, Uganda; jbtumuhairwe@caes.mak.ac.ug \\ * Correspondence: baloo@uoeld.ac.ke
}

check for updates

Citation: Aloo, B.N.; Mbega, E.R.; Makumba, B.A.; Tumuhairwe, J.B Effects of Carrier Materials and Storage Temperatures on the Viability and Stability of Three Biofertilizer Inoculants Obtained from Potato (Solanum tuberosum L.) Rhizosphere. Agriculture 2022, 12, 140.

https://doi.org/10.3390/ agriculture12020140

Academic Editor: Luciano Beneduce

Received: 20 July 2021

Accepted: 7 September 2021

Published: 20 January 2022

Publisher's Note: MDPI stays neutral with regard to jurisdictional claims in published maps and institutional affiliations.

Copyright: (C) 2022 by the authors. Licensee MDPI, Basel, Switzerland. This article is an open access article distributed under the terms and conditions of the Creative Commons Attribution (CC BY) license (https:// creativecommons.org/licenses/by/ $4.0 /)$.

\begin{abstract}
Biofertilizer technology continues to be derailed by the short shelf life of inoculants. The present study investigated the suitability of wheat-bran (WB), rice-husks (RH), farmyard-manure (FYM), bagasse (BG), and sawdust (SD) in the formulation of potato-derived Klebsiella grimontii (MPUS7), Serratia marcescens (NGAS9), and Citrobacter freundii (LUTT5) under refrigerated $\left(8^{\circ} \mathrm{C}\right)$ and room $\left(25 \pm 2{ }^{\circ} \mathrm{C}\right)$ storage. The physicochemical properties of the materials were assessed before sterilization and introduction of the inoculants and assessment of their viability for 8 months. Most of the physicochemical properties of the materials varied significantly $(p<0.05)$. Bagasse supported the maximum growth of MPUS7 (5.331 $\log$ CFU g ${ }^{-1}$ ) under refrigeration and LUTT5 (4.094 $\log$ CFU g $^{-1}$ ) under both conditions. Under room storage, the maximum growth of MPUS7 (3.721 $\log \mathrm{CFU} \mathrm{g}^{-1}$ ) occurred in WB. Formulations that remained viable under room storage can easily be integrated into existing agricultural distribution systems that lack refrigeration.
\end{abstract}

Keywords: rhizobacteria; carrier materials; biofertilizer; bioformulations; shelf-life

\section{Introduction}

Conventional agricultural practices are a major contributor to environmental pollution, global warming, and climate change [1], especially from the use of artificial fertilizers, which are widely associated with greenhouse gas emissions [2]. As such, attempts to find suitable alternative crop fertilization mechanisms and promote agricultural sustainability are quickly gathering momentum worldwide [3]. It is propounded that soil microbiota are key to the development of sustainable cropping systems [4], and plant rhizospheres have been the center of focus for researchers for decades worldwide.

Various plant-root inhabiting bacteria (rhizobacteria) can promote plant growth through various biochemical processes [5], like the production of phytohormones and siderophores, solubilization of phosphates, and biological nitrogen fixation [6,7]. Such beneficial rhizobacteria can be optimized and formulated into biofertilizers for sustainable crop production using different carrier materials [8].

The concept of biofertilizers is widely researched and there exist several practical applications globally, the utilization of this technology [9]. The use of agricultural wastes as carriers for biofertilizer formulations is one commonly explored option because of their ready availability and cost-effectiveness [10]. However, the survivability and efficiency of rhizobacterial inoculants in biofertilizer formulations are greatly dependent on the choice of carrier materials and storage temperatures [11,12]. As such, designing effective biofertilizers with long shelf lives is the greatest bottleneck for biofertilizer technology [10]. Although 
various formulations have been evaluated to date, the shelf-life data of most organic formulations are still grossly inadequate. Research should be intensified to develop stable, functional, and reliable biofertilizer inoculants as tools for sustainable agriculture [13]. The present study aimed to investigate the effects of different agricultural wastes as carrier materials for the formulation of selected potato rhizobacterial inoculants and to evaluate their survivability and stability at the end of a storage period under two different temperature conditions. This will ultimately inform us on the suitable carriers and storage conditions for the studied rhizobacterial inoculants and others for sustainable agricultural systems.

\section{Materials and Methods}

\subsection{Rhizobacterial Strains}

Potato tubers and rhizosphere soils were sampled from different parts of Tanzania in June 2018. External rhizobacterial strains were isolated from the soil samples by serial dilution (up to $10^{-3}$ ) using sterile saline water ( $\frac{1}{4}$ strength Ringer's solution), plating $1 \mathrm{~mL}$ aliquots of the $10^{-3}$ dilution on Tryptic Soy Agar (TSA), and incubating at $28 \pm 2{ }^{\circ} \mathrm{C}$ for $48 \mathrm{~h}$ [14]. For endophytic isolates, the potato tubers were washed with running tap water and sterilized with $70 \%(v / v)$ ethanol and $2 \%(w / v)$ sodium hypochlorite for $30 \mathrm{~s}$ and $10 \mathrm{~min}$, respectively, followed by rinsing with sterile distilled water [14] and isolation as described by Aravind et al. [15]. Three rhizobacterial strains, MPUS7, NGAS9, and LUTT5, and identified as Klebsiella grimontii, Serratia marcescens, and Citrobacter freundii, respectively, were selected from among the obtained isolates based on preliminary analyses of their in vitro plant growth-promoting abilities and effects on growth of potted potato plants and later characterized [16] for the formulation of biofertilizers. The GenBank accession numbers of these isolates are CP047604, СP047605, and CP047606, respectively.

\subsection{Characterization of Carrier Materials and Formulation of Biofertilizers}

Approximately $3.5 \mathrm{~kg}$ (dry weight) of 5 types of agricultural wastes (bagasse (BG), farmyard manure (FYM), rice husks (RH), sawdust (SD), and wheat bran (WB)) were sourced from locally available agro-industries in Arusha for use as carrier materials. The $\mathrm{pH}$ of the materials was determined as described by Arora et al. [17]. The carrier materials were sterilized in the oven for $24 \mathrm{~h}$ at $105^{\circ} \mathrm{C}$ and the sterilization efficiency was confirmed by plating out $1 \mathrm{~g}$ aliquots of samples on TSA and observing no growth after incubating at $28 \pm 2{ }^{\circ} \mathrm{C}$ for another $24 \mathrm{~h}$. The final (\%) moisture contents (MC) were determined on a wet and dry mass basis as expressed in Equation (1).

$$
(\%) \text { Moisture content }=\frac{\text { Mass before drying }(g)-\text { Mass of dry sample }(g)}{\text { Mass of sample before drying }(g)} \times 100 \%
$$

The water holding capacity (WHC) of each material was assessed using the KeenRaczkowski cup method following the procedures described by Joshi and Setty [18] and Equation (2).

$$
(\%) \text { WHC }=\frac{\text { Mass of saturated and drained sample }(g)-\text { Mass of dry sample }(g)}{\text { Mass of dry sample }(g)} \times 100 \%
$$

The electrical conductivity (EC) of carriers was determined using the saturated paste method (Chi and Wang, 2010) while the organic carbon (OC) and organic matter (OM) contents were evaluated using the potassium dichromate wet digestion method [19]. The $\mathrm{N}$ contents were quantified using the micro-Kjeldahl method [20] while the Mehlich III extraction method [21] was used to extract exchangeable $\mathrm{Zn}$ and $\mathrm{P}$ from materials. The ammonium acetate extraction method [22] and the 1, 10-phenanthroline complex method [23] were used to extract exchangeable $\mathrm{K}$ and $\mathrm{Fe}$ from the carriers, respectively. To estimate the quantities of $\mathrm{P}, \mathrm{K}, \mathrm{Zn}$, and Fe in the respective carrier extracts, their optical densities were obtained spectrophotometrically at A690, A799, A399, and A510, respectively, using a multi-mode reader (Synergy HTX-Biotek). The quantities of $\mathrm{P}, \mathrm{K}$, and $\mathrm{Zn}$ in $\mathrm{mg} \mathrm{kg}^{-1}$ 
were calculated from standard curves prepared from standard solutions of $\mathrm{KH}_{2} \mathrm{PO}_{4}, \mathrm{KCl}$, $\mathrm{ZnSO}_{4}$ and $\mathrm{Fe}\left(\mathrm{NH}_{4}\right)_{2}\left(\mathrm{SO}_{4}\right)_{2} \cdot 6 \mathrm{H}_{2} \mathrm{O}$, respectively.

The rhizobacterial strains were multiplied in TSB medium by inoculating and incubating at $28 \pm 2{ }^{\circ} \mathrm{C}$ in a shaking incubator ( $180 \mathrm{rpm}$ ) for $24 \mathrm{~h}$ for them to attain log phase growth with a cell load of about $1.8 \times 10^{6} \mathrm{CFU} \mathrm{mL} \mathrm{mL}^{-1}[24,25]$. The carriers were used to formulate biofertilizers for the 3 rhizobacterial inoculants (K. grimontii MPUS7, S. marcescens NGAS9, and C. freundii LUTT5) following the procedure described by Abd El-Fattah [24]. For each of the 3 inoculants, two sets of each sterilized carrier material $(\sim 20 \mathrm{~g})$ were packed in sterile high-density clear plastic containers $(40 \times 30 \times 15 \mathrm{~cm})$ in triplicates for storage at $8{ }^{\circ} \mathrm{C}$ and $25 \pm 2{ }^{\circ} \mathrm{C}$, respectively, for the monthly evaluations of inoculant viability. A summary of the design used to formulate these biofertilizers is shown in Table 1.

Table 1. A summary of the design used to formulate biofertilizers out of the rhizobacterial inoculants.

\begin{tabular}{cccccccc}
\hline Carrier Material & & BG $^{\mathbf{1}}$ & FYM $^{\mathbf{2}}$ & SD $^{\mathbf{3}}$ & $\mathbf{W B}^{\mathbf{4}}$ & $\mathbf{R H}^{\mathbf{5}}$ & Purpose \\
\hline Klebsiella grimontii & Set 1 & $20 \mathrm{~g}$ & $20 \mathrm{~g}$ & $20 \mathrm{~g}$ & $20 \mathrm{~g}$ & $20 \mathrm{~g}$ & $8^{\circ} \mathrm{C}$ storage \\
MPUS7 & Set 2 & $20 \mathrm{~g}$ & $20 \mathrm{~g}$ & $20 \mathrm{~g}$ & $20 \mathrm{~g}$ & $20 \mathrm{~g}$ & $25^{\circ} \mathrm{C}$ storage \\
\hline Serratia marcescens & Set 1 & $20 \mathrm{~g}$ & $20 \mathrm{~g}$ & $20 \mathrm{~g}$ & $20 \mathrm{~g}$ & $20 \mathrm{~g}$ & $8^{\circ} \mathrm{C}$ storage \\
NGAS9 & Set 2 & $20 \mathrm{~g}$ & $20 \mathrm{~g}$ & $20 \mathrm{~g}$ & $20 \mathrm{~g}$ & $20 \mathrm{~g}$ & $25^{\circ} \mathrm{C}$ storage \\
\hline Citrobacter freundii & Set 1 & $20 \mathrm{~g}$ & $20 \mathrm{~g}$ & $20 \mathrm{~g}$ & $20 \mathrm{~g}$ & $20 \mathrm{~g}$ & $8^{\circ} \mathrm{C}$ storage \\
LUTT5 & Set 2 & $20 \mathrm{~g}$ & $20 \mathrm{~g}$ & $20 \mathrm{~g}$ & $20 \mathrm{~g}$ & $20 \mathrm{~g}$ & $25^{\circ} \mathrm{C}$ storage \\
\hline
\end{tabular}

${ }^{1}$ Bagasse, ${ }^{2}$ Farmyard manure, ${ }^{3}$ Sawdust, ${ }^{4}$ Wheat bran, ${ }^{5}$ Rice husks.

The preparations were thoroughly mixed in sterile Petri-dishes $(90 \mathrm{~mm})$ using sterile glass rods to ensure uniformity in distribution and absorption of the liquid cultures into the carriers and left to cure under sterile conditions in the laminar flow hood for $24 \mathrm{~h}$, repackaged in the sterile plastic containers and sealed aseptically. The 1st sets of each bio-formulation were stored at $8{ }^{\circ} \mathrm{C}$ and the 2 nd sets at room temperature $\left(25 \pm 2{ }^{\circ} \mathrm{C}\right)$ for the purpose of determining the conducive storage temperatures. The total number of formulations was thus, 30. During the experiment, aliquots of non-inoculated carrier materials were maintained under the same incubation conditions to check the maintenance of axenic conditions. The biofertilizers packaged for storage are displayed in Figure 1.

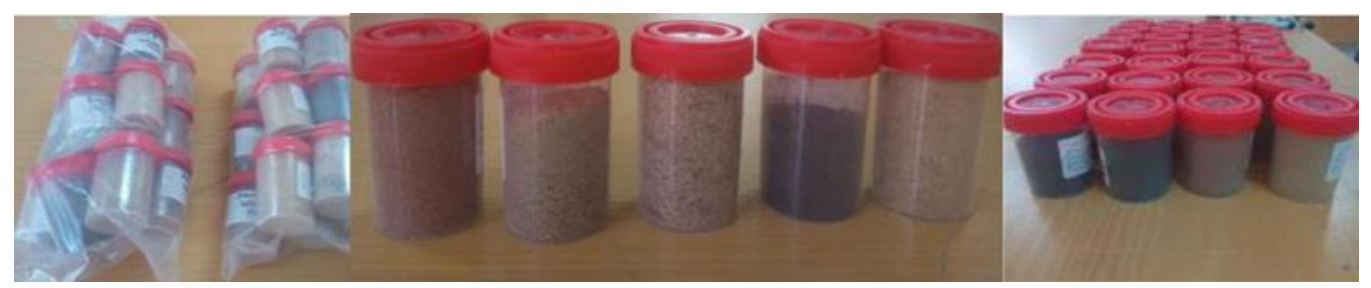

Figure 1. Formulated biofertilizers packaged in different carrier materials for storage and monthly evaluations.

\subsection{Laboratory Evaluation of the Viability of the Biofertilizer Formulations}

Periodical samples were taken aseptically from each of the 30 formulations for 8 consecutive months for evaluation of the stability and viability of the rhizobacterial inoculants. Sampling was done by scooping about $1 \mathrm{~g}$ of each formulation using a sterile spatula and suspending in $9 \mathrm{~mL}$ of sterile distilled water, followed by vigorous mixing and filtering in Whatman (No. filter papers. The number of viable cells $\mathrm{g}^{-1}$ of each formulation was determined using the plate count technique $\left(28^{\circ} \mathrm{C} ; 24 \mathrm{~h}\right)$ using the prepared filtrates on TSA plates $[24,25]$.

\subsection{Statistical Analyses}

All statistical analyses were performed using the XLSTAT (Version 2.3, Adinsoft) at a $95 \%$ level of confidence. The Shapiro-Wilk test was used to test for normality of 
data and multiple comparisons of variances were performed using Multivariate Analysis of Variance (MANOVA). Variables with significantly different means were subjected to posthoc analysis using Tukey's Honest Significant Difference (HSD) test. A t-test for paired samples was used to evaluate the viability of the biofertilizer formulations in the different carrier materials under room and refrigerated storage.

\section{Results and Discussions}

\subsection{The Physicochemical Characteristics of the Carrier Materials}

The physicochemical properties of the carrier materials that were used in the formulation of biofertilizers are portrayed in Table 2. According to Gade et al. [26], these properties can largely affect inoculant survival and viability. The results showed that the materials were moderately acidic ( $\mathrm{pH} 4.73 \pm 0.13$ to $5.4 \pm 0.21$ ) except for FYM which was slightly alkaline ( $\mathrm{pH} 8.38 \pm 0.24)$. Such $\mathrm{pH}$, which is generally near-neutral, is known to support large inoculant populations and maintain their viability [27-29] and maintain their viability.

Table 2. Characteristics of the carrier materials used in the formulation of biofertilizers for in vitro and field evaluations.

\begin{tabular}{|c|c|c|c|c|c|c|c|}
\hline & Sawdust & Wheat Bran & FYM & Bagasse & Rice Husks & Average & $p$ Value \\
\hline $\mathrm{pH}$ & $4.73 \pm 0.13^{b}$ & $4.63 \pm 1.07^{b}$ & $8.38 \pm 0.24^{a}$ & $4.35 \pm 0.19^{b}$ & $5.37 \pm 0.21^{b}$ & $5.49 \pm 1.59$ & $0.000 *$ \\
\hline $\mathrm{EC}\left(\mathrm{uS} \mathrm{cm}{ }^{-1}\right)$ & $0.116 \pm 0.027^{\mathrm{c}}$ & $1.174 \pm 0.634^{\mathrm{ab}}$ & $1.985 \pm 0.349^{\mathbf{a}}$ & $0.194 \pm 0.062^{\mathrm{c}}$ & $0.89 \pm 0.026^{b c}$ & $0.993 \pm 0.853$ & $0.000 *$ \\
\hline WHC (\%) & $388 \pm 22^{b}$ & $155 \pm 28^{c}$ & $101 \pm 7^{c}$ & $568 \pm 90^{a}$ & $62 \pm 46^{c}$ & $255 \pm 203$ & $0.000 *$ \\
\hline MC (\%) & $17.1 \pm 0.6^{\mathbf{a}}$ & $10.3^{\prime} \pm 0.5^{\mathbf{b}}$ & $15.8 \pm 1.4^{\mathrm{a}}$ & $8.6 \pm 1.5^{b}$ & $8.2 \pm 0.3^{\mathbf{b}}$ & $11.9 \pm 3.9$ & $0.000 *$ \\
\hline N (\%) & $0.100 \pm 0.03$ & $0.060 \pm 0.04$ & $0.130 \pm 0.01$ & $0.090 \pm 0.08$ & $0.160 \pm 0.01$ & $0.110 \pm 0.05$ & 0.154 \\
\hline OC (\%) & $1.84 \pm 0.17$ & $0.70 \pm 0.51$ & $1.45 \pm 0.14$ & $1.07 \pm 0.92$ & $1.31 \pm 0.37$ & $1.27 \pm 0.58$ & 0.154 \\
\hline OM (\%) & $3.17 \pm 0.28$ & $1.20 \pm 0.88$ & $2.50 \pm 0.24$ & $1.85 \pm 1.58$ & $2.25 \pm 0.63$ & $2.20 \pm 1.00$ & 0.152 \\
\hline$P\left(\mathrm{mg} \mathrm{kg}^{-1}\right)$ & $248.7 \pm 103.7^{\mathbf{b}}$ & $323.6 \pm 109.2^{\mathbf{b}}$ & $1354.6 \pm 68.9^{a}$ & $183.3 \pm 29.9^{b}$ & $270.8 \pm 64.4^{\mathbf{b}}$ & $476.2 \pm 462.0$ & $0.000 *$ \\
\hline $\mathrm{K}\left(\mathrm{mg} \mathrm{kg}^{-1}\right)$ & $9.26 \pm 5.16$ & $9.06 \pm 1.44$ & $11.70 \pm 0.96$ & $6.24 \pm 0.52$ & $7.49 \pm 0.96$ & $8.75 \pm 2.99$ & 0.225 \\
\hline $\mathrm{Zn}\left(\mathrm{mg} \mathrm{kg}^{-1}\right)$ & $221.3 \pm 136.5^{\mathrm{ab}}$ & $203.8 \pm 69.33^{\mathrm{ab}}$ & $442.6 \pm 30.99^{a}$ & $87.4 \pm 33.22^{b}$ & $266.1 \pm 192.4^{\mathrm{ab}}$ & $244.2 \pm 152.3$ & $0.034^{*}$ \\
\hline $\mathrm{Fe}\left(\mathrm{mg} \mathrm{kg}^{-1}\right)$ & $0.99 \pm 0.29^{\mathbf{b}}$ & $1.24 \pm 0.49^{b}$ & $3.68 \pm 1.62^{a}$ & $0.72 \pm 0.14^{b}$ & $0.84 \pm 0.33^{b}$ & $1.49 \pm 1.32$ & $0.005^{*}$ \\
\hline
\end{tabular}

The average EC of carrier materials ranged from $\sim 0.116$ to $1.985 \mathrm{dS} \mathrm{cm}^{-1}$. The average EC of RH and BG were $0.89 \pm 0.23$ and $0.19 \pm 0.06 \mathrm{dS} \mathrm{m}^{-1}$, respectively. However, in a study by Khavazi et al. [30] these two carriers portrayed a relatively higher average EC of $\sim 4.20$ and $1.62 \mathrm{dS} \mathrm{m}^{-1}$, respectively. Similar findings in the range of 3.89 to $4.03 \mathrm{dS} \mathrm{m}^{-1}$ have also been reported by Abdel Nabi et al., (2016). The EC of carrier materials depicts the concentration of soluble salts which can definitely influence the activities and survivability of inoculants.

The WHC of the carrier materials ranged from about 62 to $387 \%$. The average WHC of WB, FYM and RH were all $<150 \%$ while BG portrayed the greatest average WHC of $568 \pm 90 \%$ followed distantly by SD at $388 \pm 22 \%$. High WHC $(>50 \%)$ is a desirable feature in carrier materials to support proper bacterial growth and multiplication $[28,29,31]$. In the present study, the WHC of the carrier materials ranged from 62 to $387 \%$, suggesting their potential as carriers for biofertilizer production. This is because high WHC favors the enzymatic processes involved in the degradation of the organic materials that provide important nutrients for bacteria [32]. These present findings are also comparable to previous reports $[26,27,30]$. Sawdust had the 2nd highest average WHC (388 $\pm 22 \%)$ after BG (568 $\pm 90 \%)$, agreeing with previous reports about its suitability for biofertilizer formulation $[17,25]$.

The MC of the carrier materials ranged from 8.2 to $17.1 \%$. Additionally, FYM and SD had significantly higher MC averages of $15.8 \pm 1.4 \%$ and $17.1 \pm 0.6 \%$, respectively, than WB, SD, and BG. Arora et al. [27], while studying different organic carrier materials, 
similarly reported an average MC of $16.8 \%$ but BG had a lower average MC of $6.8 \%$. The $\mathrm{MC}$ of carrier materials can exert a great effect on inoculant survival and longevity [11,33]. Generally, dry formulations with low MC can extend microbial survival for longer periods and at higher temperatures, subsequently reducing marketing and maintenance costs since refrigeration is not required [34]. This is probably because the inoculants can remain inactive and resistant to environmental stresses and insensitive to contamination in carriers with low MC [33].

Generally, the carrier materials were rich in C, N, K, and micronutrients (Fe and Zn) which makes them suitable for microbial growth because these macro and micro-nutrients are required for carbohydrate metabolism [28], protein synthesis, enzyme activation and different growth processes of microbes [35]. For N, OC and OM, averages of $0.100 \pm 0.1 \%$, $1.3 \pm 0.6 \%$ and $2.2 \pm 1 \%$ were recorded, respectively. Farmyard manure seemed to contain more macro and micronutrients than the other carrier materials but its Zn content was not significantly higher $(p>0.05)$ than the rest except for BG. For N, OC and OM, averages of $0.100 \pm 0.1 \%, 1.3 \pm 0.6 \%$ and $2.2 \pm 1 \%$ were recorded, respectively, in FYM. Previous studies also indicate that FYM contains 0.500 to $1.000 \% \mathrm{~N}[36,37]$, while RH and BG, averagely $0.400 \%$ [30]. The SD in this study also contained substantially high OC/OM which makes it a desirable carrier material [17]. Generally, carrier materials with high OM content can increase bacterial survival and enhance the efficacy of bio-formulations [38], by supporting proper inoculant growth and multiplication [31].

\subsection{Laboratory Evaluation of the Viability and Stability of the Formulated Biofertilizers}

\subsubsection{Laboratory Evaluation of the Shelf Life of the Formulated Biofertilizer}

The present study also investigated the viability and stability of rhizobacterial biofertilizers that were formulated from the five different carrier materials (WB, SD, FYM, RH, and BG) for 8 months (February-September 2019) under refrigeration $\left(8^{\circ} \mathrm{C}\right)$ and room storage $\left(25 \pm 2{ }^{\circ} \mathrm{C}\right)$. The results are displayed in Figure $2 \mathrm{a}-\mathrm{f}$. The determination of shelf lives of formulations is a crucial step during the development of biofertilizers [8,39], and the prolonged survival of inoculants during storage is a desirable feature that can enhance the industrial applicability of biofertilizer formulations [8].

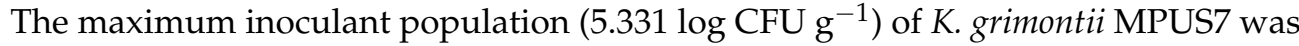
achieved in BG after 4 months of storage under refrigeration but the FYM formulation also maintained relatively high K. grimontii MPUS7 populations for most of the storage period under the same conditions (Figure 2a), a strong indication of its potential suitability as a carrier for this inoculant under refrigeration, probably due to its lower average MC $(8.62 \pm 1.45 \%)$ which may make inoculants to remain relatively inactive and resistant to environmental stresses [33]. The WB formulation did not sufficiently maintain high K. grimontii MPUS7 populations under refrigeration and by the 7th month of storage, no viable cells were detected from this formulation. Nevertheless, carriers that can maintain inoculants for at least 2-3 months are still suitable for commercial purposes [39,40]. Interestingly, under room storage, the WB formulation maintained the highest inoculant populations for most of the storage period except from the 7 th month onwards where the inoculant population dropped to $1.5 \log \mathrm{CFU} \mathrm{g}^{-1}$ below levels observed in the other formulations (Figure 2b). Although the storage of biofertilizers is mostly reported to be better under refrigeration than room conditions [26,41-43], the present results show that WB could sufficiently maintain K. grimontii MPUS7 under room storage, which may allow for its integration in the existing agricultural distribution systems that lack refrigeration facilities [44]. 

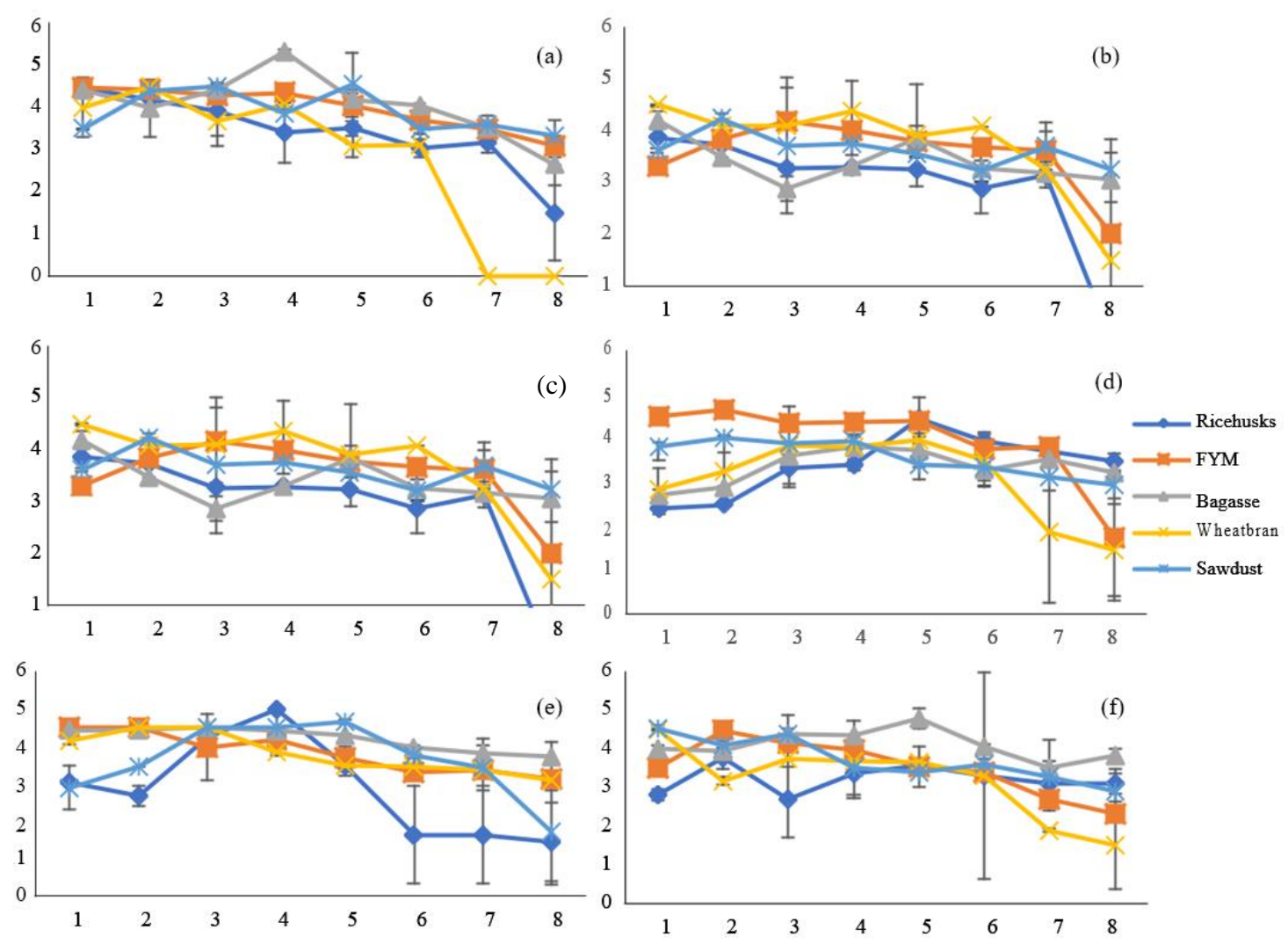

Month

Figure 2. The 8-month viability of the formulated biofertilizers under room and refrigerated conditions in different carrier materials. The graphs represent $K$. grimontii MPUS7 under refrigerated (a) and room (b) storage, S. marcescens NGAS9 under refrigerated (c) and room (d) storage, and C. freundii LUTT5 under refrigerated (e) and room (f) storage in the different carrier materials. The point values are means of three replicates \pm standard deviation. The $y$-axes represent the $\operatorname{Log~CFU~g}^{-1}$ of the biofertilizer formulations.

Similar observations were made for FYM formulation which also maintained relatively high inoculant populations for most of the storage period and by the 8th month, the population of inoculants was still $2.0 \log \mathrm{CFU} \mathrm{g}^{-1}$. Under these conditions, the inoculant populations in $\mathrm{RH}$ and WB formulations dropped to $0.0 \mathrm{CFU} \mathrm{g}{ }^{-1}$ and $1.5 \log \mathrm{CFU} \mathrm{g}^{-1}$, respectively, by the 8 th month of storage. Farmyard manure, WB, BG, and SD formulations could all maintain high $S$. marcescens NGAS9 populations throughout the study period under refrigerated conditions (Figure 2c), demonstrating their suitability in supporting the growth and multiplication of this inoculant. Although previous studies have demonstrated $\mathrm{RH}$ as a good carrier material for inoculant formulation [25,31,45], such results were not replicated in the present study for $S$. marcescens NGAS9 under refrigeration (Figure 2c) probably due to physiological differences among inoculants [46].

Under room storage, the formulations could all maintain sufficient $S$. marcescens NGAS9 populations during the entire storage period (Figure 2d), suggesting their suitability for the formulation of this inoculant and storage under room conditions which can allow for its integration into existing agricultural distribution channels that lack refrigeration facilities [44]. The suitability of these materials as carriers for other inoculants under room storage has also been demonstrated for other inoculants [27,47]. By the 8 th month of room storage, only FYM and WB formulations had low inoculant populations $\left(<1.5 \log \mathrm{CFU} \mathrm{g}^{-1}\right)$. 
The BG formulation maintained consistently high C. freundii LUTT5 populations throughout the study period under refrigeration (Figure 2e).

The compositional analysis of BG has in earlier studies revealed that it is equipped with monosaccharides, hemicellulose, and amino acids that together make it a nutritionally rich material for microbial growth [48]. In a similar study, when BG formulations were stored at $4{ }^{\circ} \mathrm{C}$ for 6 months, the survival of inoculants was high and densities of $10^{9}$ cells g ${ }^{-1}$ were maintained [30]. Under room storage, C. freundii LUTT5 populations did not vary widely in the formulations (Figure 2f). Nevertheless, the BG formulation proved to be the best at maintaining high C. freundii LUTT5 populations and by the 8th month of storage, this formulation still had an average of $3.8 \log \mathrm{CFU} \mathrm{g}^{-1}$. Bagasse has also been reported to maintain high numbers of $P$. fluorescens $\left(9.3 \log \mathrm{CFU} \mathrm{g}{ }^{-1}\right.$ ) and R. leguminosarum (8.9 $\left.\log \mathrm{CFU} \mathrm{g}{ }^{-1}\right)$ after 6 months of room storage $\left(25 \pm 2{ }^{\circ} \mathrm{C}\right)$ [27]. The shelf life of inoculants depends on several factors including the production technology, carrier material, storage conditions, and packaging material [49]. In the present study, the shelf lives of the formulated biofertilizers were only established in terms of the storage conditions and carrier materials. The viability of inoculums in formulations for a sufficient period is important for the commercialization and applicability of biofertilizers [27]. However, it should be noted that inoculant survival in carriers is not only vital during storage but also after introduction in the soil where they have to compete with well-established indigenous soil microbes [40].

\subsubsection{Comparative Effects of Storage Temperatures on the Viability of Biofertilizer Formations}

The present study evaluated the viability of each of the biofertilizer formulations in different carrier materials under room $\left(25 \pm 2{ }^{\circ} \mathrm{C}\right)$ and refrigerated $\left(8^{\circ} \mathrm{C}\right)$ conditions using the t-test for paired samples/two-tailed tests. The results are portrayed in Figure 3a-o. Temperature is one of the factors that affect the longevity and survival of inoculants and should be evaluated to optimize storage conditions for long-term inoculant survival $[11,33]$. Significant differences $(p<0.05)$ were noted between the number of viable cells under room $\left(25 \pm 2{ }^{\circ} \mathrm{C}\right)$ and refrigerated $\left(8^{\circ} \mathrm{C}\right)$ conditions for the $\mathrm{WB}$ formulations of all 3 biofertilizer inoculants (Figure $3 \mathrm{a}-\mathrm{c}$ ). In a study by Sandikar and Awasthi [42], biofertilizer inoculants also showed a maximum population under refrigeration $\left(8^{\circ} \mathrm{C}\right)$. The prolonged shelf life of inoculants under refrigeration has previously been linked to the reduction of metabolic activities and physiological activities [26,41]. While investigating the shelf lives of Rhizobium carrier-based biofertilizers under different storage temperatures, refrigeration $\left(8^{\circ} \mathrm{C}\right)$ was also demonstrated to be more suitable for inoculant viability probably because of lowered MC at higher temperatures [43].

Except for K. grimontii MPUS7, the viability of the tested inoculants in the RH formulations although not significant, seemed to be better under refrigeration than room storage (Figure 3j-1). Similar to the observations made for FYM formulations, the viability of inoculants in the BG formulations also seemed to be better under refrigerated conditions (Figure $3 \mathrm{k}-\mathrm{o}$ ). For the SD formulations, the number of viable cells of the three inoculants was also greater under refrigerated than room storage (Figure $3 \mathrm{~d}-\mathrm{f}$ ). However, significant differences in 14 these numbers between the two conditions were only evident for S. marcescens NGAS9 ( $p=0.001$ ) (Figure 3e). Similarly, for the FYM formulations, the number of viable cells of all three biofertilizer inoculants was higher under refrigerated conditions but this was only significant for C. freundii LUTT5 $(p=0.020)$ (Figure 3g-i). Due to the biological nature of inocula, the survival of formulated cells at room temperature for longer storage is a persistent problem probably due to their growth and metabolic activities which lead to $\mathrm{pH}$ changes, death, and loss of viability [50]. 


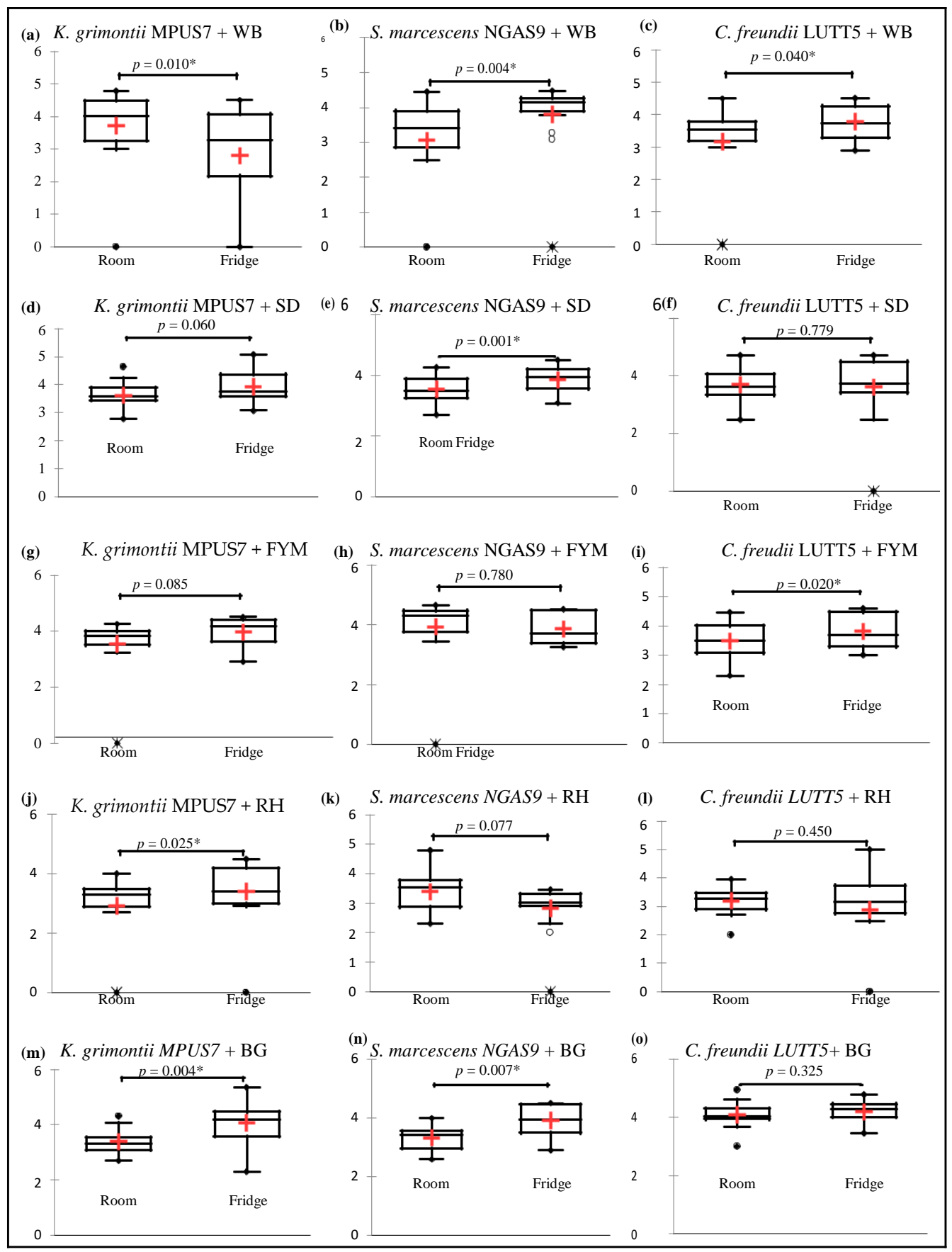

Figure 3. Comparative evaluation of the stability and viability of K. grimontii MPUS7, S. marcescens NGAS9 and C. freundii LUTT5, formulated in wheat bran (WB), sawdust (SD) and farmyard manure (FYM), rice husks (RH) and bagasse (BG) under room and refrigerated storage. Values are means of three replicates \pm standard deviation. The y-axes represent the $\log \mathrm{CFU} \mathrm{g}^{-1}$ of the biofertilizer formulations. * Significantly different at $p<0.05$. Significant differences in inoculant means between room and refrigerated storage were obtained for K. grimontii MPUS7 + WB (a), S. marcescens NGAS9 + WB (b), C. freundii LUTT5 + WB (c), S. marcescens NGAS9 + SD (e), C. freundii LUTT5 + FYM (i), K. grimontii MPUS7 + RH (j), K. grimontii MPUS 7 + BG (m), and S. marcescens NGAS9 + BG (n). No significant differences were observed for the mean inoculant numbers between room and refrigerated storage for K. grimontii MPUS7 + SD (d), C. freundii LUTT5 + SD (f), K. grimontii MPUS7 + FYM (g), S. marcescens NGAS9 + FYM (h), S. marcescens NGAS9 + RH (k), C. freundii LUTT5 + RH (1), and C. freundii LUTT5 + BG (o). 
Unlike S. marcescens NGAS9 (Figure 3b) and C. freundii LUTT5 (Figure 3c), the number of viable cells of $K$. grimontii MPUS7 in the WB formulation was significantly higher under room storage $\left(3.7 \pm 1.1 \log \mathrm{CFU} \mathrm{g}{ }^{-1}\right)$ than refrigerated conditions $\left(2.8 \pm 1.7 \log \mathrm{CFU} \mathrm{g}^{-1}\right)$ (Figure 3a). Similar observations were also made for $S$. marcescens in FYM (Figure 3h) and $\mathrm{RH}$ (Figure 3k). These results demonstrate that these formulations can easily be integrated into existing agricultural distribution systems that lack refrigeration facilities [44].

\subsubsection{Comparative Effects of Carrier Materials on the Viability of Biofertilizer Formations}

The viability of the biofertilizer inoculants in different carrier materials under room and refrigerated conditions were also evaluated using the students' t-test for independent variables. The comparative effects of the studied carrier materials on the stability of the inoculants are shown in Table 3. Under room conditions, the WB, SD, FYM, and RH formulations almost equally supported the viability and stability of the three inoculants. However, for the BG formulations, significant differences $(p \leq 0.0001)$ were noted for the population of the three inoculants and this formulation seemed to support the growth of C. freundii LUTT5 better than K. grimontii MPUS7 and S. marcescens NGAS9 under the same storage conditions. This may be related to the physiological differences between these rhizobacterial species coupled with carrier-based factors [11,26,30,51]. Under refrigeration, however, significant differences of inoculant populations were only noted for the WB formulations ( $p=0.038$ ) while the rest of the carrier-based formulations equally supported and maintained the viability of all three biofertilizer inoculants during the experimental period. These results are probably due to the differences in the physicochemical properties of the carrier materials [11,30,51]. Despite having the greatest nutrient contents among the studied carriers, FYM did not significantly influence the stability of inoculants probably because it was also more alkaline ( $\mathrm{pH} 8.38)$ and had a higher $\mathrm{MC}(15.8 \%)$ since these properties are not suitable for inoculant survival and viability $[28,29,34]$.

Table 3. Comparative evaluation of the viability of K. grimontii MPUS7, S. marcescens NGAS9 and C. freundii LUTT5 $\left(\log \mathrm{CFU} \mathrm{g}{ }^{-1}\right.$ ) in different carrier materials under room and refrigerated storage.

\begin{tabular}{|c|c|c|c|c|}
\hline Storage Conditions & $\begin{array}{l}\text { K. grimontii } \\
\text { MPUS7 }\end{array}$ & $\begin{array}{c}\text { S. marcescens } \\
\text { NGAS9 }\end{array}$ & $\begin{array}{l}\text { C. freundii } \\
\text { LUTT5 }\end{array}$ & $p$ Value \\
\hline \multicolumn{5}{|c|}{ Room Conditions $\left(25 \pm 2{ }^{\circ} \mathrm{C}\right)$} \\
\hline Wheat Bran & $3.721 \pm 1.107^{\mathrm{a}}$ & $3.055 \pm 1.265^{\mathrm{a}}$ & $3.168 \pm 1.267^{\mathrm{a}}$ & 0.285 \\
\hline Sawdust & $3.626 \pm 0.464^{\mathrm{a}}$ & $3.544 \pm 0.414^{\mathrm{a}}$ & $3.697 \pm 0.599^{a}$ & 0.702 \\
\hline Farm Yard Manure & $3.548 \pm 0.962^{\mathrm{a}}$ & $3.935 \pm 1.077^{\mathrm{a}}$ & $3.495 \pm 0.694^{\mathrm{a}}$ & 0.372 \\
\hline Rice Husks & $2.921 \pm 1.159^{a}$ & $3.385 \pm 0.670^{\mathbf{a}}$ & $3.202 \pm 0.463^{\mathrm{a}}$ & 0.302 \\
\hline Bagasse & $3.398 \pm 0.418^{\mathbf{b}}$ & $3.351 \pm 0.404^{\mathbf{b}}$ & $4.094 \pm 0.424^{\mathbf{a}}$ & $<0.0001$ \\
\hline \multicolumn{5}{|c|}{ Refrigerated Conditions $\left(8^{\circ} \mathrm{C}\right)$} \\
\hline Wheat Bran & $2.799 \pm 1.694^{b}$ & $3.806 \pm 1.056^{\mathrm{a}}$ & $3.792 \pm 0.515^{a}$ & 0.038 \\
\hline Sawdust & $3.934 \pm 0.506^{\mathbf{a}}$ & $3.850 \pm 0.478^{\mathrm{a}}$ & $3.607 \pm 1.125^{\mathrm{a}}$ & 0.482 \\
\hline Farm Yard Manure & $3.977 \pm 0.509^{\mathrm{a}}$ & $3.868 \pm 0.512^{\mathrm{a}}$ & $3.825 \pm 0.561^{a}$ & 0.702 \\
\hline Rice Husks & $3.401 \pm 1.039^{\mathrm{a}}$ & $2.829 \pm 0.826^{\mathrm{a}}$ & $2.855 \pm 1.553^{\mathrm{a}}$ & 0.351 \\
\hline Bagasse & $4.071 \pm 0.755^{\mathrm{a}}$ & $3.927 \pm 0.516^{\mathbf{a}}$ & $4.187 \pm 0.353^{\mathrm{a}}$ & 0.456 \\
\hline
\end{tabular}

Values are means of three replicates \pm standard deviation of the mean. Values with the same letter superscripts in the same row are not significantly different $(p>0.05$; $t$-test for paired samples).

The choice of carrier material is one of the factors that affects the efficacy of biofertilizer formulations $[11,30,51]$, and can greatly enhance the shelf life and performance of microbial inoculants $[12,35,40]$. When selecting carrier materials for biofertilizer formulation, it is necessary to use those that can support high cell numbers to achieve longer shelf lives and increase their usability. The present study investigated was on various agricultural wastes as carriers for biofertilizer formulation because they are rich sources of nutrients for microbial growth and are readily available [10]. This not only makes them cheap but also contributes to the reduction of pollution by putting the agricultural wastes into 
reuse [38]. These materials were also selected because of their solid nature which makes them compatible with the application technologies for conventional fertilizers.

The overall observations showed that the numbers of viable cells significantly declined in all bio-formulations during the incubation period, similar to previous observations [52]. Such declines may be attributed to the depletion of nutrients, moisture, and autolysis of cells $[10,11,41]$. At the moment, various efforts in the biofertilizer technology are aimed at selecting carriers and developing novel formulations that can support high inoculant populations and plant growth $[25,39]$, and this study provides the baseline regarding the survivability of various inoculants in organic carrier materials.

\title{
4. Conclusions
}

Except for OC, OM and K quantities, the carrier materials had significantly different physicochemical properties which can greatly influence their suitability as carriers for inoculants. Most of the rhizobacterial formulations could be stored for up to 6 months under both room and refrigerated conditions. Nevertheless, the viability and stability of the inoculants in the formulations seemed better under refrigeration. The carrier materials and storage temperatures both influenced inoculant stability and viability. This study sets a good platform for further explorations into the potential of the formulations for the biofertilization of potatoes and other crops under controlled and field experiments.

\begin{abstract}
Author Contributions: Conceptualization, B.N.A. and E.R.M.; methodology, B.A.M. and J.B.T.; investigation and data collection, B.N.A.; writing—original draft preparation, B.N.A.; writing-review and editing, E.R.M., B.A.M. and J.B.T.; supervision, E.R.M., B.A.M. and J.B.T.; project administration, B.N.A.; funding acquisition, B.N.A. and J.B.T. All authors have read and agreed to the published version of the manuscript.
\end{abstract}

Funding: This research was funded by DAAD, grant number 91671357 and the APC was funded by L'Oreal-UNESCO Foundation For Women in Science, and the African -German Network of Excellence in Science (AGNES), with generous funding from the Federal Ministry of Education and Research (BMBF), and the Alexander von Humboldt Foundation (AvH).

Institutional Review Board Statement: Not Applicable.

Data Availability Statement: All data relating to this work is presented within the article.

Acknowledgments: The authors acknowledge University of Eldoret for providing financial support to the lead author to conduct the study. The authors also acknowledge Dalmas Mnyang'ali for the echnical support offered during the laboratory experiments.

Conflicts of Interest: The authors declare no conflict of interest.

\section{References}

1. Bellarby, J.; Stirling, C.; Vetter, S.H.; Kassie, M.; Kanampiu, F.; Sonder, K.; Smith, P.; Hillier, J. Identifying Secure and Low Carbon Food Production Practices: A Case Study in Kenya and Ethiopia. Agric. Ecosyst. Environ. 2014, 197, 137-146. [CrossRef]

2. Di Benedetto, N.A.; Corbo, M.R.; Campaniello, D.; Cataldi, M.P.; Bevilacqua, A.; Sinigaglia, M.; Flagella, Z. The Role of Plant Growth Promoting Bacteria in Improving Nitrogen Use Efficiency for Sustainable Crop Production: A Focus on Wheat. AIMS Microbiol. 2017, 3, 413. [CrossRef]

3. Kumar, A.; Verma, H.; Singh, V.K.; Singh, P.P.; Singh, S.K.; Ansari, W.A.; Yadav, A.; Singh, P.; Pandey, K. Role of Pseudomonas sp. in Sustainable Agriculture and Disease Management. In Agriculturally Important Microbes for Sustainable Agriculture; Meena, V.S., Mishra, P.K., Bisht, J.K., Pattanayak, A., Eds.; Springer: Singapore, 2017; pp. 195-215.

4. Bender, S.F.; Wagg, C.; van der Heijden, M.G. An Underground Revolution: Biodiversity and Soil Ecological Engineering for Agricultural Sustainability. Trends Ecol. Evol. 2016, 31, 440-452. [CrossRef] [PubMed]

5. Vessey, J.K. Plant Growth Promoting Rhizobacteria as Biofertilizers. Plant Soil 2003, 255, 571-586. [CrossRef]

6. Kumar, A.; Patel, J.S.; Meena, V.S. Rhizospheric Microbes for Sustainable Agriculture: An Overview. In Role of Rhizospheric Microbes in Soil; Meena, V., Ed.; Springer Nature: Singapore, 2018; pp. 1-31.

7. Patel, T.S.; Minocheherhomji, F.P. Plant Growth Promoting Rhizobacteria: Blessing to Agriculture. Int. J. Pure Appl. Biosci. 2018, 6, 481-492. [CrossRef]

8. Bashan, Y.; de-Bashan, L.E.; Prabhu, S.; Hernandez, J.-P. Advances in Plant Growth-Promoting Bacterial Inoculant Technology: Formulations and Practical Perspectives (1998-2013) (A Marshner Review). Plant Soil 2014, 378, 1-33. [CrossRef] 
9. Tabassum, B.; Khan, A.; Tariq, M.; Ramzan, M.; Khan, M.S.I.; Shahid, N.; Aaliya, K. Bottlenecks in Commercialisation and Future Prospects of PGPR. Appl. Soil Ecol. 2017, 121, 102-117. [CrossRef]

10. Shaikh, S.; Sayyed, R. Role of Plant Growth-Promoting Rhizobacteria and their Formulation in Biocontrol of Plant Diseases. In Plant Microbes Symbiosis: Applied Facets; Arora, N.K., Ed.; Springer: New Delhi, India, 2015; pp. 337-351.

11. Sohaib, M.; Zahir, Z.A.; Khan, M.Y.; Ans, M.; Asghar, H.N.; Yasin, S.; Al-Barakah, F.N. Comparative Evaluation of Different Carrier-Based Multi-Strain Bacterial Formulations to Mitigate the Salt Stress in Wheat. Saudi J. Biol. Sci. 2020, 27, 777-787. [CrossRef]

12. Sudjana, B.; Jingga, A.; Simarmata, T. Enriched Rice Husk Biochar Ameliorant to Increase Crop Productivity on Typic Hapludults Glob. Adv. Res. J. Agric. Sci. 2017, 6, 108-113.

13. Seema, K.; Mehta, K.; Singh, N. Studies on the Effect of Plant Growth Promoting Rhizobacteria (PGPR) on Growth, Physiological Parameters, Yield and Fruit Quality of Strawberry Cv. Chandler. J. Pharmacogn. Phytochem. 2018, 7, 383-387.

14. Elbeltagy, A.; Nishioka, K.; Suzuki, H.; Sato, T.; Sato, Y.-I.; Morisaki, H.; Mitsui, H.; Minamisawa, K. Isolation and Characterization of Endophytic Bacteria from Wild and Traditionally Cultivated Rice Varieties. Soil Sci. Plant Nutr. 2000, 46, 617-629. [CrossRef]

15. Aravind, R.; Kumar, A.; Eapen, S.; Ramana, K. Endophytic Bacterial Flora in Root and Stem Tissues of Black Pepper (Piper Nigrum L.) Genotype: Isolation, Identification and Evaluation against Phytophthora Capsici. Lett. Appl. Microbiol. 2009, 48, 58-64. [CrossRef]

16. Aloo, B.N.; Mbega, E.R.; Makumba, B.A.; Hertel, R.; Daniel, R. Molecular Identification and in Vitro Plant Growth-Promoting Activities of Culturable Potato (Solanum Tuberosum L.) Rhizobacteria in Tanzania. Potato Res. 2021, 64, 67-95. [CrossRef]

17. Arora, N.; Kumar, V.; Maheshwari, D. Constraints, development and future of the inoculants with special reference to rhizobial inoculants. In Innovative Approaches in Microbiology; Maheshwari, D.K., Dubey, R.C., Eds.; Singh and Singh: Dehradun, India, 2001; pp. 241-245.

18. Joshi, M.; Setty, P.T.K. A Text Book of Irrigation and Water Management; Kalyani Publishers: Ludhiana, India, 2005.

19. Walkley, A.; Black, I.A. An Examination of the Degtjareff Method for Determining Soil Organic Matter, and a Proposed Modification of the Chromic Acid Titration Method. Soil Sci. 1934, 37, 29-38. [CrossRef]

20. Bremner, J.M.; Mulvaney, C.S. Nitrogen-total. In Methods of Soil Analysis; Agronomy Monographs; American Society of Agronomy: Madison, WI, USA, 2015; Volume 5, pp. 595-624.

21. Tran, S.; Simard, R. Mehlich III-Extractable Elements. In Soil Sampling and Methods of Analysis; Carter, M.R., Ed.; CRC Press: Boca Raton, FL, USA, 1993; pp. 43-49.

22. Jackson, M. Soil Chemical Analysis, 2nd ed.; Prentice Hall of India: New Delhi, India, 1973.

23. Chaurasia, S.; Gupta, A.D.; Gupta, D. Handbook of Water, Air and Soil Analysis; International Science Congress Association: Chhattisgarh, India, 2014

24. Abd El-Fattah, D.A.; Eweda, W.E.; Zayed, M.S.; Hassanein, M.K. Effect of Carrier Materials, Sterilization Method, and Storage Temperature on Survival and Biological Activities of Azotobacter Chroococcum Inoculant. Ann. Agric. Sci. 2013, 58, 111-118. [CrossRef]

25. Vishwakarma, K.; Kumar, V.; Tripathi, D.K.; Sharma, S. Characterization of Rhizobacterial Isolates from Brassica Juncea for Multitrait Plant Growth Promotion and Their Viability Studies on Carriers. Environ. Sustain. 2018, 1, 253-265. [CrossRef]

26. Gade, R.M.; Chaithanya, B.H.; Khurade, K.C. A Comparative Study of Different Carriers for Shelflife of Pseudomonas Fluorescens. Bioscan 2014, 9, 287-290.

27. Arora, N.K.; Ekta, K.; Narain, R.; Maheshwari, D.K. Sawdust as a Superior for Production of Multipurpose Bioinoculant Using Plant Growth Promoting Rhizobium Spp and Pseudomonas Spp Strains and Their Impact on Productivity of Trifolium Repense. Curr. Sci. 2008, 95, 90-94.

28. Shahzad, S.; Khan, M.Y.; Zahir, Z.A.; Asghar, H.N.; Chaudhary, U.K. Comparative Effectiveness of Different Carriers to Improve the Efficacy of Bacterial Consortium for Enhancing Wheat Production under Salt Affected Field Conditions. Pak. J. Bot. 2017, 49, 1523-1530.

29. Sahu, P.K.; Brahmaprakash, G.P. Formulations of Biofertilizers-Approaches and Advances. In Microbial Inoculants in Sustainable Agricultural Productivity: Functional Applications; Singh, D.P., Singh, H.B., Prabha, R., Eds.; Springer: New Delhi, India, 2016; Volume 2, pp. 179-198. ISBN 978-81-322-2644-4.

30. Khavazi, K.; Rejali, F.; Seguin, P.; Miransari, M. Effects of Carrier, Sterilization Method, and Incubation on Survival of Bradyrhizobium Japonicum in Soybean (Glycine Max L.) Inoculants. Enzyme Microb. Tech. 2007, 41, 780-784. [CrossRef]

31. Mahdi, S.S.; Hassan, G.; Samsoon, S.; Rather, H.; Dar, S.A.; Zehra, B. Biofertilizers in Organic Agriculture. J. Phytol. 2010, 2, 42-54.

32. Rebah, B.F.; Prevost, D.; Yezza, A.; Tyagi, R.D. Agro-Industrial Waste Material and Wastewater Sludge for Rhizobial Inoculant Production: A Review. Bioresour. Technol. 2007, 98, 3535-3546.

33. Zayed, M.S. Advances in Formulation Development Technologies. In Microbial Inoculants in Sustainable Agricultural Productivity, Functional Applications; Singh, D.P., Singh, H.B., Prabha, R., Eds.; Springer: New Delhi, India, 2016; pp. $219-237$.

34. Melin, P.; Håkansson, S.; Eberhard, T.H.; Schnürer, J. Survival of the Biocontrol Yeast Pichia Anomala after Long-Term Storage in Liquid Formulations at Different Temperatures, Assessed by Flow Cytometry. J. Appl. Microbiol. 2006, 100, 264-271. [CrossRef]

35. Pandey, P.; Maheshwari, D.K. Bioformulation of Burkholderia Sp. MSSP with a Multispecies Consortium for Growth Promotion of Cajanus Cajan. Can. J. Microbiol. 2007, 53, 213-222. [CrossRef] [PubMed] 
36. Bahadur, I.; Maurya, B.; Roy, P.; Kumar, A. Potassium-Solubilizing Bacteria (KSB): A Microbial Tool for K-Solubility, Cycling, and Availability to Plants. In Plant Growth Promoting Rhizobacteria for Agricultural Sustainability; Kumar, A., Meena, V., Eds.; Springer: Singapore, 2019; pp. 257-265.

37. Chandrasekaran, B.; Annadurai, K.; Somasundaram, E. A Text Book of Agronomy; New Age International Publishers: New Delhi, India, 2010.

38. Itelima, J.U.; Bhang, W.J.; Onyimba, I.A. A Review: Biofertilizer; a Key Player in Enhancing Soil Fertility and Crop Productivity. J. Microbiol. Biotechnol. Rep. 2018, 2, 22-28.

39. Lobo, C.B.; Juárez Tomás, M.S.; Viruel, E.; Ferrero, M.A.; Lucca, M.E. Development of Low-Cost Formulations of Plant GrowthPromoting Bacteria to Be Used as Inoculants in Beneficial Agricultural Technologies. Microb. Res. 2019, 219, 12-25. [CrossRef] [PubMed]

40. Malusá, E.; Sas-Paszt, L.; Ciesielska, J. Technologies for Beneficial Microorganisms Inocula Used as Biofertilizers. Sci. World J. 2012, 2012, 491206. [CrossRef]

41. Phiromtam, M.; Mala, T.; Srinives, P. Effect of Various Carriers and Storage Temperatures on Survival of Azotobacter Vinelandii NDD-CK-1 in Powder Inoculant. Mod. Appl. Sci. 2013, 7, 81-89.

42. Sandikar, B.M.; Awasthi, R.S. Preparation and Shelf-Life Study of Pseudomonas and Bacillus Bioformulations against Phytopathogenic Pythium and Fusarium Species. Int. J. Plant Prot. 2010, 2, 251-254.

43. Thirumal, G.; Reddy, R.S.; Triveni, S.; Nagaraju, Y.; Prasannakumar, B. Screening of Native Rhizobia and Pseudomonas Strains for Plant Growth Promoting Activities. Int. J. Curr. Microbiol. App. Sci. 2017, 6, 616-625. [CrossRef]

44. Nakkreen, S.; Fernando, D.W.G.; Siddiqui, Z.A. Plant growth promoting rhizobacteria formulations and its scope in commercialization for the management of pests and diseases. In Biocontrol and Biofertilization; Siddiqui, Z.A., Ed.; Springer: Dordrecht, Netherlands, 2005; pp. 257-296.

45. Chakraborty, A.; Hu, C.X. Lending Relationships in Line-of-Credit and Nonline-of-Credit Loans: Evidence from Collateral Use in Small Business. J. Financ. Intermediation 2006, 15, 86-107. [CrossRef]

46. Vassilev, N.; Vassilev, M.; Lopez, A.; Martos, V.; Reyes, A.; Maksimovic, I.; EichlerLöbermann, B.; Malusá, E. Unexploited Potential of Some Biotechnological Techniques for Biofertilizer Production and Formulation. Appl. Microb. Biotechnol. 2015, 99, 4983-4996. [CrossRef]

47. Arora, N.K.; Tiwari, S.; Singh, R. Comparative Study of Different Carriers Inoculated with Nodule Forming and Free Living Plant Growth Promoting Bacteria Suitable for Sustainable Agriculture. J. Pharm. Chem. Biol. Sci. 2014, 2, $143-149$.

48. Du Toit, P.J.; Olivier, S.P.; van Biljon, P.L. Sugar Cane Bagasse as a Possible Source of Fermentable Carbohydrates. Characterization of Bagasse with Regard to Monosaccharide, Hemicellulose, and Amino Acid Composition. Biotech. Bioeng. 1984, 26, 1071-1079. [CrossRef] [PubMed]

49. Arora, N.K.; Maheshwari, D.K.; Khare, E. Plant growth promoting rhizobacteria: Constraints in bioformulation, commercialization and future strategies. In Bacteria and Plant Health; Maheshwari, D.K., Ed.; Springer: Berlin, Germany, 2010; pp. 97-116.

50. Bharti, N.; Sharma, S.K.; Saini, S.; Verma, A.; Nimonkar, V.; Prakash, O. Microbial Plant Probiotics: Problems in Application and Formulation. In Probiotics and Plant Health; Kumar, V., Kumar, M., Sharma, S., Prasad, R., Eds.; Springer: Singapore, 2017; pp. 317-335.

51. Ma, Y. Seed Coating with Beneficial Microorganisms for Precision Agriculture. Biotechnol. Adv. 2019, 2019, 107423. [CrossRef]

52. Kumar, V. Characterization, Bio-Formulation Development and Shelf-Life Studies of Locally Isolated Bio-Fertilizer Strains. Oct. J. Environ. Res. 2014, 2, 32-37. 